\title{
The Differences in Mentzer Index between Cyanotic and Acyanotic Congenital Heart Diseases
}

\author{
Santa Ulina*, Rizky Adriansyah, Ayodhia Pitaloka Pasaribu \\ *dr.santa.marpaung@gmail.com \\ Department of Child Health, Faculty of Medicine, University of Sumatera Utara, Medan, Indonesia \\ Jl. Dr. Mansyur No.5 Padang Bulan, Medan Baru, Medan, North Sumatera, Indonesia
}

\begin{abstract}
The prevalence of congenital heart diseases (CHDs) was estimated to be $8-12$ per 1000 live births. Around $77.8 \%$ and $87.2 \%$ of cyanotic and asyanotic CHD cases experienced decrease in iron levels in the blood respectively. Anemia in children with CHDs, especially with cyanosis and high hematocrit levels due to chronic hypoxia, were often underdiagnosed. The Mentzer index as a diagnostic tool for anemia was used to diagnose iron deficiency in children with cyanotic and acyanotic CHDs. This research was a cross-sectional study done in Haji Adam Malik hospital by using data from medical records. Among 110 samples, TOF and VSD were diagnosed the most in cyanotic and acyanotic CHDs respectively in children aged $1-5$ years old. Hematological parameters such as hemoglobin, hematocrit and erythrocyte showed significant value $(\mathrm{p}<0.05)$ statistically. The difference of the Mentzer index with Mann-Whitney test showed significant difference $(\mathrm{p}<0.05)$ with median value of $12.0 \pm 3.9$ and $17.2 \pm 4.2$ in cyanotic and acyanotic CHD respectively.
\end{abstract}

Published by IJRP.ORG. Selection and/or peer-review under responsibility of International Journal of Research Publications (IJRP.ORG)

Keywords: Mentzer index; iron deficiency; congenital heart disease

\section{Introduction}

Congenital heart diseases (CHDs) are the most common congenital disorder found. The prevalence of CHDs was estimated to be 8-12 cases per 1000 live births (Susan et al., 2019). Children with CHDs often suffer from iron deficiency anemia, which was caused by multiple factors. In 114 children with CHDs, $85 \%$ needed iron supplementation (Maloku-Ceku and Berisha, 2010). The prevalence of children with iron deficiency anemia in Indonesia remains high. From the data by Basic Health Research (Riskesdas) Indonesia, the prevalence of anemia in North Sumatra in year 2007 was $16.5 \%$. While in 2013, almost $30 \%$ children aged $1-14$ years old suffered from anemia (Depkes RI, 2007; Depkes RI, 2013).

Both cyanotic and acyanotic congenital heart diseases have risks of iron reserves depletion in the body. The study by Mukherjee et al., (2018) showed 5 to 10 patients with cyanotic CHDs suffered from iron deficiency (Mukherjee et al., 2018). Meanwhile, Binh et al., (2018) reported $77.8 \%$ and $87.2 \%$ cyanotic and acyanotic CHD patients respectively suffered from the decrease in iron levels in the blood. Hemoglobin (Hb) concentration within normal range may imply that cyanotic CHD patients were relative anemia. This condition may have negative effects to mortality and morbidity (Binh et al., 2018). Soni et al., (2018) compared normal population as the control group to cyanotic CHD cases and reported 56.7\% cases of iron deficiency (Soni et al., 2018). From the existing research, iron deficiency in congenital heart diseases needed to be enforced by serum ferritin, serum iron (SI), and total iron binding capacity (TIBC) level checks (Mukherjee et al., 2018). Those examinations, however, require special equipment, specialists in hematology, and high in cost.

Anemia in children with CHDs, especially cyanotic children who showed high haematocrit levels due to chronic hypoxia, were often under diagnosed. Therefore, there is a need of screening tools that can be easily applied in everyday life, even when no haematologists are available, for early detection with affordable price. In some literature, the Mentzer index (MI) was used as an early screening tool to differentiate iron deficiency anemia from thalassemia (Alam et al., 2014, Djer and Madiyono, 2016, Martínez-Quintan and Rodríguez-González, 2013, Okoromah et al., 2011).

The Mentzer index (MI) is one of the discrimination index formulas developed as a thalassemia trait test to distinguish thalassemia with other hypochromic microcytic anemia, especially iron deficiency anemia. The calculation is done by dividing the average cell volumes or mean corpuscular volume (MCV) with total IJRP 2021, 77(1), 1-8; doi:.10.47119/IJRP100771520211928 
erythrocytes, where values greater than 13 are predictors from iron deficiency anemia. In several past studies about the MI values $>13$ concluded good sensitivity and specificity values at $93 \%$ and $84 \%$ respectively to enforce iron deficiency anemia (Alam et al., 2014, Djer and Madiyono, 2016, Martínez-Quintan and Rodríguez-González, 2013, Okoromah et al., 2011). Niazi et al., 2010 did a research on patients with iron deficiency anemia in Pakistan for the sensitivity and specificity of seven screening methods to differentiate thalassemia trait from iron deficiency, such as RDWI, Mentzer, Green \& Kings, Srivastava, Ricerca, England Fraser, and Shine Lal, concluded that the highest diagnosis accuracy was RDW index (88.14\%), followed by Mentzer index (86.85\%) (Niazi et al., 2010). Vehapoglu et al., (2014) also conducted a research to 290 children with thalassemia and anemia. They found that the MI has $98.7 \%$ and $82.3 \%$ sensitivity and specificity respectively. Meanwhile, Youdan index had $81 \%$ accuracy for thalassemia filter test, which was the highest compared to other discrimination indices (Vehapoglu et al., 2014). Another study by Ehsani et al., (2009) showed that the best screening index based on Youden criteria was the Mentzer index (90.1\%), followed by RDW index (85.5\%) (Ehsani et al., 2009). Today, there has not been a study that used the MI as one of the formulas for iron deficiency anemia early screening in patients with cyanotic and acyanotic congenital heart diseases.

\section{Methods}

This study was a cross-sectional study by assessing the differences between the Mentzer index and both cyanotic and acyanotic congenital heart diseases. Sampling technique used was non-probability sampling by consecutive sampling method from medical records in Haji Adam Malike Hospital between January 2018 and December 2019. Inclusion criteria were patients aged $\geq 6$ months old with congenital heart diseases based on diagnosis by echocardiography and having complete medical records. Exclusion criteria were patients who had received iron supplementation for $>1$ month before receiving treatment in Haji Adam Malik hospital and patients with no complete routine blood test results.

Congenital heart disease diagnosis was enforced by echocardiography results. Data such as age, gender, medical record number, as well as the hematological parameters (hemoglobin, hematocrit, and erythrocyte levels) from Haji Adam Malik hospital blood test laboratory by Sysmex XN-1000 equipment was collected. The Mentzer index was calculated by dividing MCV with erythrocyte levels. The results were categorized into IM $\geq 13$ and IM $<13$.

This study had received research approval from Health Research Ethics Committee of Medical Faculty, Universitas Sumatera Utara (No. 902/TGL/KEPK FK USU-RSUP HAM/2019).

\subsection{Data analysis}

Data processing was performed by using Statistical Package Social Sciences for Windows (SPSS) version 21 computerized system. Mann-Whitney test was used to measure the correlation between the Mentzer index and the hematological parameters, whereas unpaired t-test was used to measure the differences between the Mentzer index and both cyanotic and acyanotic congenital heart diseases.

\section{Results}

\subsection{Research subject characteristic data}

There were 110 children meeting the inclusion criteria in this study. They were divided into two groups, such as 55 cyanotic CHD and 55 acyanotic CHD children. Data was recorded from the inpatient and outpatient medical records of pediatric cardiology in Haji Adam Malik Hospital Medan between January 2018 and December 2019. Table 1 shows the characteristic data of research subjects.

Table 1. Research subject characteristic

\begin{tabular}{|c|c|}
\hline \multirow{2}{*}{ Characteristic } & Congenital heart disease \\
\hline & Acyanotic \\
\hline
\end{tabular}




\begin{tabular}{|c|c|c|}
\hline Male & $31(56.4)$ & $24(43.6)$ \\
\hline Female & $24(43.6)$ & $31(56.4)$ \\
\hline \multicolumn{3}{|l|}{ Age, years old, $n(\%)$} \\
\hline$<1$ year old & $2(3.6)$ & $5(9.1)$ \\
\hline $1-5$ years old & $24(43.6)$ & $23(41.8)$ \\
\hline $6-12$ years old & $21(38.2)$ & $19(14.5)$ \\
\hline $13-18$ years old & $8(14.5)$ & $8(14.5)$ \\
\hline \multicolumn{3}{|c|}{ Nutritional status, $n(\%)$} \\
\hline Malnutrition & $8(14.5)$ & $15(27.3)$ \\
\hline Poor nutrition & $30(54.5)$ & $28(50.9)$ \\
\hline Good nutrition & $17(30.9)$ & $11(20)$ \\
\hline overweight & - & $1(1,8)$ \\
\hline \multicolumn{3}{|l|}{ Hemoglobin, $n(\%)$} \\
\hline Low & $4(7.3)$ & $11(20)$ \\
\hline Normal & $15(27.3)$ & $39(70.9)$ \\
\hline Hight & $36(65.5)$ & $5(9.1)$ \\
\hline \multicolumn{3}{|l|}{ Hematocrit, $n(\%)$} \\
\hline Low & $2(3.6)$ & $10(18.2)$ \\
\hline Normal & $10(18.2)$ & $39(70.9)$ \\
\hline High & $43(78.2)$ & $6(10.9)$ \\
\hline \multicolumn{3}{|l|}{$\mathrm{MCV}, n(\%)$} \\
\hline Microcytic & $14(25.5)$ & $7(12.7)$ \\
\hline Normal & $11(20)$ & $15(27.3)$ \\
\hline Macrocytic & $30(54.5)$ & $33(60)$ \\
\hline \multicolumn{3}{|l|}{ Erythrocytes, $n(\%)$} \\
\hline Low & $3(5.5)$ & $23(41.8)$ \\
\hline Normal & $25(45.5)$ & $30(54.5)$ \\
\hline High & $27(49.1)$ & $2(3.6)$ \\
\hline
\end{tabular}

In cyanotic CHD group, there were $56.4 \%$ male and $43.6 \%$ female patients. Whereas in acyanotic CHD group, there were $43.6 \%$ male and $56.4 \%$ female patients. The highest incidence frequency was found in children aged $1-5$ years old $(43.6 \%$ and $41.8 \%)$ followed by children aged $6-12$ years old $(38.2 \%$ and $14.5 \%)$ in both cyanotic and acyanotic CHD groups. Almost half of the research subjects involved in the study had poor nutrition (54.5\% and 50.9\% in cyanotic and acyanotic group respectively). Based on echocardiography results, the highest diagnosis for cyanotic CHD was TOF (44 subjects), followed by TGA (7 subjects), double outlet right ventricle (DORV) (3 subjects), and truncus arteriosus (1 subject). While in acyanotic CHD group, the highest diagnosis was ventricular septal defect (VSD) (30 subjects), patent ducus arteriosus (PDA) (17 subjects), and atrial septal defect (ASD) (8 subjects). The data is shown in Figure 1 below.

Hematological parameters observed in this study was hemoglobin $(\mathrm{Hb})$, hematocrit $(\mathrm{Ht})$, mean corpuscular volume (MCV), and erythrocytes (Eri). In cyanotic CHD group, 36 samples (65.6\%) had high Hb level, 15 samples (27.3\%) had normal $\mathrm{Hb}$ levels, and 4 samples (7.3\%) had low Hb levels. Whereas in acyanotic group, 43 samples (78.2\%) had normal Hb levels, 11 samples (20\%) had low Hb levels, and 5 samples (9.1\%) had high $\mathrm{Hb}$ levels. As for Ht levels, in cyanotic CHD group, 43 samples (78.2\%) and 10 samples (18.2\%) had high and normal Ht levels respectively. As for acyanotic CHD group, 39 samples (70.9\%) and 10 samples (18.2\%) had normal and low Ht levels. 
Fig. 1. Cyanotic and acyanotic congenital heart disease diagnosis

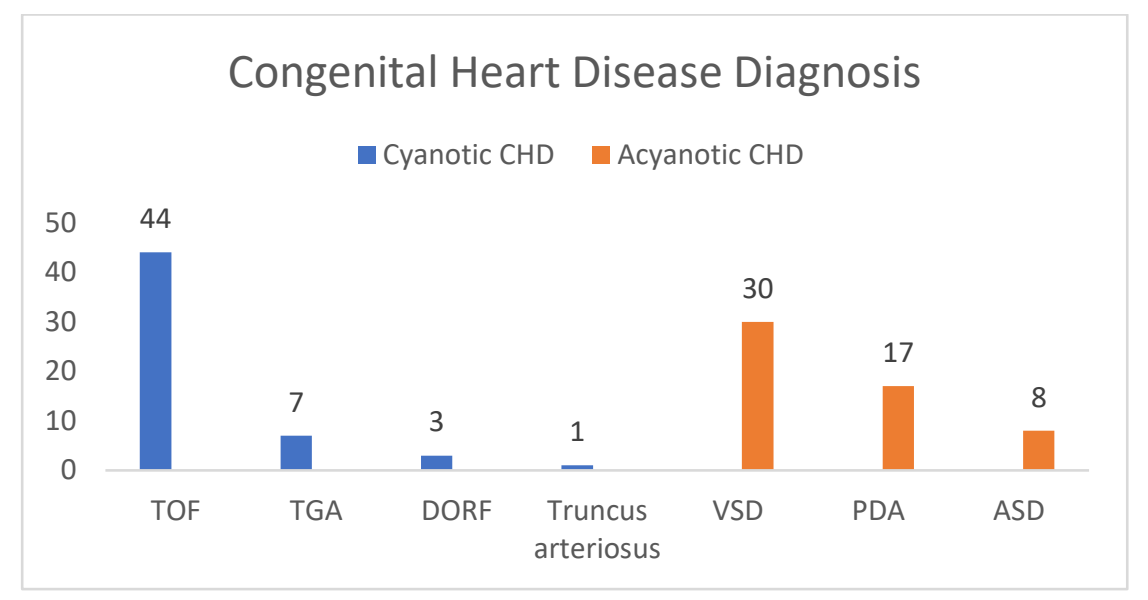

\subsection{The relationship between the Mentzer index and hematological parameters}

The Mentzer index (MI) and hematological parameters were tested by Mann-Whitney test as shown in Table 2. The relationship between the MI value and hematological parameters, such as $\mathrm{Hb}, \mathrm{Ht}$ and Eri was significant $(\mathrm{p}<0.05)$. In both cyanotic and acyanotic CHDs, the median values ( $\min -\max$ ) of the MI were $11.8(4.7-21.86)$ and $17.2(4.92-27.54)$ respectively. Whereas, the median values ( $\min -\max )$ of Hb levels in cyanotic and acyanotic CHDs were $17(7.2-26.8)$ and $12.4(8-19.3)$ respectively.

Table 2 The differences between the Mentzer index and hematological parameters

\begin{tabular}{|c|c|c|c|}
\hline Parameter & $\begin{array}{l}\text { Cyanotic } \\
(n=55)\end{array}$ & $\begin{array}{c}\text { Acyanotic } \\
(\mathbf{n}=55)\end{array}$ & $\mathbf{P}$ \\
\hline $\begin{array}{l}\text { Mentzer Index, median (min- } \\
\max )\end{array}$ & $\begin{array}{c}11.8 \\
(4.7-21.86)\end{array}$ & $\begin{array}{c}17.2 \\
(4.92-27,54)\end{array}$ & 0.00 \\
\hline $\begin{array}{l}\text { Hemoglobin, median (min-max), } \\
\text { mg/dL }\end{array}$ & $\begin{array}{c}17.0 \\
(7.2-26.8)\end{array}$ & $\begin{array}{c}12.4 \\
(8-19.3)\end{array}$ & 0.00 \\
\hline $\begin{array}{l}\text { Hematocrit, median (min-max), } \\
\quad \%\end{array}$ & $\begin{array}{c}53.0 \\
(25-81)\end{array}$ & $\begin{array}{c}37.0 \\
(25-58)\end{array}$ & 0.00 \\
\hline MCV, median (min-max), fL & $\begin{array}{c}81.0 \\
(28-105)\end{array}$ & $\begin{array}{c}80 \\
(29.3-96)\end{array}$ & 0.53 \\
\hline $\begin{array}{l}\text { Erythrocyte, median } \\
(\min -\max ), \text { million } / \mu \mathrm{L}\end{array}$ & $\begin{array}{c}6.4 \\
(3.4-10.54)\end{array}$ & $\begin{array}{c}4.5 \\
(3.1-7.4)\end{array}$ & 0.00 \\
\hline
\end{tabular}

\subsection{The relationship between the Mentzer index and congenital heart diseases}

The differences between the Mentzer index and both cyanotic and acyanotic CHDs by unpaired t-test was statistically significant with $\mathrm{p}<0.05$. Table 3 below shows the relationship between the MI and congenital heart diseases.

Table 3. The differences between the Mentzer index and congenital heart diseases

\begin{tabular}{lccc}
\hline \multirow{2}{*}{ Mentzer Index } & \multicolumn{2}{c}{ Congenital heart diseases } & P \\
\cline { 2 - 3 } & Cyanotic & Acyanotic & \\
\hline$\geq 13$ & 20 & 48 & 0.00 \\
$<13$ & 35 & 7 & \\
\hline
\end{tabular}




\section{Discussion}

Congenital heart diseases (CHDs) occurred in every 8 live births (Bernier et al., 2010). This study was a cross-sectional study that assessed the differences between the Mentzer index and congenital heart diseases both cyanotic and acyanotic. The Mentzer index was a method used to differentiate iron deficiency anemia from minor thalassemia found by Mentzer in 1973. The index of mean corpuscular volume (MCV) in fL was divided by red blood cells (in million per microliter). The values of each data could be observed from the results of complete laboratory blood test (Ferdian et al., 2009).

In the basic characteristic of research sample data, most subjects were male (56.4\%) in cyanotic CHD, while in acyanotic CHD, more female patients (56.4\%) were observed. The study done by Nikyar et al., (2008) where babies born with CHDs were observed in Dezyani hospital, Iran. The prevalence was 8.6 CHDs per 1000 live births, where most patients were male with a ratio of 9.96 and 7.34 per 100. Moreover, the risk of CHD incidences was 1.35 higher in male than in female $(\mathrm{OR}=1.35)$ (Nikyar et al., 2011). Similar research was done by Hermawan et al., (2018) by observing CHD profile in Dr. M. Djamil hospital Padang. They reported higher incidence rate in male patients where 42 patients $(49.42 \%)$ with cyanotic CHDs, 27 patients $(31.76 \%)$ with acyanotic CHDs and 16 patients (18.82\%) were suffering from combined CHDs (Hermawan et al., 2018). The past studies showed higher incidence rate of congenital heart diseases in male than in female.

In the study, patients treated with CHDs were in $1-5$ and $6-12$ year-old age groups. There were 24 subjects (43.6\%) and 21 subjects (38.2\%) in cyanotic group in the $1-5$ and $6-12$ year-old age groups respectively, and 23 subjects (41.8\%) and 19 subjects (14.5\%) in acyanotic group respectively. Past studies also reported that most CHD cases were found in toddlers ( $>1$ year old). Hermawan et al., (2018) reported that most children were at the age of $>1$ year old when they were diagnosed with CHDs. Another supporting study was done by Maramis et al., (2014) in Manado, who reported higher cases of CHDs in $1-6$ year-old age group within 4 years (Hermawan et al., 2018; Maramis et al., 2014). This showed that most CHD cases were found in toddlers.

There were 30 subjects (54.5\%) and 28 subjects (50.9\%) in cyanotic and acyanotic CHDs respectively with poor nutritional status. In a case-control study done by Okoromah et al., (2011) reported 66 from 73 children with CHDs had poor nutritional status. The overall prevalence was $90.4 \%$ in case group compared to $21.1 \%$ control group (Okoromah et al., 2011). The study done by Mir et al., (2019) also reported $72.5 \%$ prevalence of poor nutritional status in 29 from 40 children with CHDs compared to $22.5 \%$ prevalence of children without CHDs but had poor nutritional status (Mir et al., 2019). Similarly, in Padang and Egypt, in the study by Hermawan et al., (2015) and Hassan et al., (2015) reported higher cases of poor nutritional status in all patients with CHDs, regardless of the type of CHDs they were suffering from (Hassan et al., 2015; Hermawan et al., 2015). The study in Egypt was a cross-sectional study done to 152 children with CHDs and reported 65.8\% malnutrition (lack and poor nutritional status), 62.5\% underweight, and 66.4\% stunting cases (Hassan et al., 2015). This study showed that cyanotic CHDs tended to affect body weight and length gain. Patients without cyanosis have slower body weight gain than body length gain. In general, the causes of malnutrition in CHD patients were the increase need of energy/calorie absorption but with inefficient utilization, inadequate calorie intake, and impaired macro and micro nutrient absorption. Children with CHDs often suffer from growth failure as they were frequently admitted to hospitals and had insufficient nutrition intake (Nydegger et al., 2009).

Cyanotic and acyanotic congenital heart diseases were enforced by echocardiography test results. Based on the type of heart defects, the highest diagnosis in cyanotic CHD was TOF (44 subjects), followed by TGA (7 subjects). While, in acyanotic CHD, the highest diagnosis was VSD (30 subjects) and PDA (17 subjects). Another study also reported ASD (34\%) and VSD (28.3\%) as the highest diagnosis in CHD patients (Maramis et al., 2016; Hariyanto, 2016).

Various results of hematological parameters ( $\mathrm{Hb}, \mathrm{Ht}, \mathrm{MCV}$, and Eri) and MI were obtained in this study. The mean values of cyanotic and acyanotic CHDs respectively were $17.0 \pm 3.5$ and $12.4 \pm 2.0$ for $\mathrm{Hb} ; 53.8 \pm 11.2$ and 37.9 \pm 6.4 for $\mathrm{Ht}$. The cross-sectional study done in Padang reported mean level for $\mathrm{Hb}$ of acyanotic CHD patients was $11.97 \mathrm{mg} / \mathrm{dL}$ and for $\mathrm{Ht}$ was $42.7 \%$ and $48.6 \%$ for acyanotic and cyanotic CHD respectively (Nydegger et al., 2009). Binh et al., (2018) reported the min and max Ht levels in cyanotic and acyanotic CHD patients were at $52.2 \pm 7.9$ and $39.1 \pm 3.2$ respectively with $P$ value 0.0001 , whereas for the min and max value of $\mathrm{Hb}$ levels were at $17.3 \pm 27.4$ and $12.8 \pm 10.3$ for cyanotic and acyanotic CHD respectively with $\mathrm{P}$ value 0.0001 (Binh et al., 2018). In cyanotic CHDs, hematocrit level increased and it caused hyperviscosity. Moreover, $\mathrm{Hb}$ level increased as well. Hyperviscosity was an incidence when blood viscosity increased, characterized by the 
increase in $\mathrm{Ht}$ or circulating plasma components. In cyanotic CHD patients, this occurred due to prolonged cyanosis. It was also associated with polycythemia and abnormal hemostasis. Polycythemia was the increase in $\mathrm{Hb}$ and $\mathrm{Ht}$ levels, which showed the mass ratio of red blood cells and plasma volume (Vaidyanathan et al., 2008; Suyasa et al., 2013; Broberg et al., 2006). Secondary erythrocytosis as a physiological response due to chronic tissue hypoxia occured in cyanotic CHDs. As a result, it stimulated erythropoiesis in the bone marrow. With low arterial oxygen levels, the bone marrow was stimulated and released erythropoietin in the kidneys. Hence the increase in red blood cells and eventually increased the red cell mass, hematocrit and blood viscosity (Vehapoglu et al., 2014; Broberg et al., 2006; Modi et al., 2004; Rose et al., 2007).

The increase in red blood cells was the compensation to allow adequate oxygen transport to the tissues. In this study, the mean numbers of erythrocytes in cyanotic and acyanotic CHDs wERE $6.8 \pm 1.5$ and $4.7 \pm 0.8$ respectively with $\mathrm{p}<0.05$. Similarly, Binh et al., (2008) reported $6.4 \pm 1.2$ and $4.8 \pm 0.5$ mean erythrocyte numbers in cyanotic and acyanotic CHDS respectively with $\mathrm{p}<0.0001$. Another parameter assessed in this study was mean MCV at 78.3 with 12.1 SD and 79.6 with 9.5 SD for cyanotic and acyanotic CHDS respectively. This results, however, were not significant statistically with p value 0.53. The study by Binh et al., (2018) also reported insignificant relationship between min - max cyanotic and acyanotic CHDS (82.8 \pm 7.2 and $81.3 \pm 6.7$ respectively) with p value 0.3748 (Binh et al., 2018).

There were many iron deficiency cases reported in cyanotic CHD patients. Iron deficiency anemia and its effects were assessed in past studies when patients had cyanotic spells, where blood viscosity and erythrocyte indices were used to asses iron deficiency anemia in cyanotic CHD patients (Binh et al., 2018; Soni et al., 2018; Broberg et al., 2006). Mukherjee et al., (2018) reported $47.06 \%$ prevalence of iron deficiency anemia in cyanotic CHD (Mukherjee et al., 2018). In a similar study by Binh et al., (2018) to 69 pediatric patients, where 36 children with cyanotic CHD and 33 children with acyanotic CHD, $11.1 \%$ and $3 \%$ cyanotic and acyanotic CHD respectively suffered from iron deficiency. The prevalence rate increased to $77.8 \%$ and $87.2 \%$ respectively for the risk of depletion and reduction in total iron in the blood. The researcher concluded that total erythrocytes and the indices could enforce iron deficiency anemia diagnosis (Binh et al., 2018).

This study used the Mentzer index (MI) value in cyanotic and acyanotic CHD to diagnose the suspicion of iron deficiency anemia. There were significant differences observed in the MI value $\geq 13$, where 20 and 48 cyanotic and acyanotic samples respectively were found significant with $p<0.00$. Meanwhile, the mean values of the Mentzer index of $12 \pm 3.9$ and 17.2 \pm 4.1 in cyanotic and acyanotic CHDs respectively were significant with $\mathrm{p}<0.00$. There has yet been a research about the MI value as an early screening tool for iron deficiency anemia in CHDs. Alam et al., (2014) conducted a diagnostic study by a cross-sectional method to school children in Palembang using the MI 13.51 cut-off point. The study reported cut-off point $\geq 13.51$ had $93 \%$ sensitivity and $84 \%$ specificity (Alam et al., 2014). The study done by Bose and Maimoon (2018) also showed 90\% sensitivity and $85 \%$ specificity for the diagnosis of iron deficiency anemia with the MI value $\geq 13$ (Bose and Maimoon, 2018). Rodríguez-Hernández et al., (2018) reported $9 \%$ of CHD patients were suffering from anemia. The number one cause of anemia was due to iron deficiency. Meanwhile, there was a lot of causes contributing to anemia incidence. The study explained that iron deficiency anemia in CHDs occurred due to acute or chronic blood loss caused by abnormal homeostasis, vascular bleeding, anticoagulant and antiplatelet drug usage, low food intake, and decrease in iron absorption due to celiac diseases, or systemic increases. Besides that, low MCV, iron, and ferritin, as well as high red blood cell distribution have emphasized that iron deficiency played important roles in the onset of anemia with normocytic erythrocyte in $40 \%$ of patients. The cut-off MCV < $95 \mathrm{fL}$ had $97.6 \%$ sensitivity showed that $95 \%$ of CHD patients suffered from iron deficiency anemia. Cyanotic and acyanotic CHDs had $60 \%$ prevalence of anemia with low MCV and increase in RDW and polycythemia (Rodríguez-Hernández et al., 2018). Another study also showed low MCV and high RDW values in anemia cases in cyanotic and acyanotic CHD patients. In the study, patients high RDW confirmed, showed increase in interleukin-6 (IL-6) level as proinflammatory cytokine that could inhibit the maturation of erythropoietin-induced erythrocytes due to the increase in RDW (Miyamoto et al., 2015). The cause of anemia was usually due to inflammation processes. Proinflammatory cytokine such as TNF- $\alpha$, interleukin-6 and interleukin-1 could interfere with erythropoiesis process such as reducing erythropoietin secretion and decreasing its activity in erythrocyte precursors in the bone marrow. Proinflammatory cytokine also increased hepcidin levels which could cause impaired iron absorption in the digestive tract in the duodenum, increased iron uptake in the macrophages, as well as slowed down the release of iron in the macrophages. With iron trapped in the macrophages, the bioavailability of iron stores to synthesize 
iron was reduced. Peripheral ischemia from anemia caused vasodilation and the decrease in blood pressure. Then it activated angiotensin-aldosterone system, reduced blood flow to the kidneys and glomerular filtration rate, as well as increased water and salt absorption. If those continued to occur, it would decrease erythropoietin in the kidneys, which was used in the erythropoiesis process to increase red blood cell production (Miyamoto et al., 2015; Beverborg et al., 2018).

The assessment of MI as an initial screening for iron deficiency anemia in cyanotic and acyanotic CHDs have not been conducted before. The application of MI $\geq 13$ as an early screening of iron deficiency anemia in CHD required further study, as the population of iron deficiency anemia subjects was different between previous studies and this research; despite this research showing statistically significant differences. The Mentzer index formula was MCV value divided by total Eri. which can reduce the validity of calculation due to conditions affecting MCV and Eri. values. The enforcement of iron deficiency anemia in CHD patients required further examination to regularly asses iron stores in the body. Therefore, the status of iron deficiency could be detected early.

\section{Conclusion}

Mentzer index had significant differences with both cyanotic and acyanotic CHD. However, there is a need of iron reserves examination to enforce iron deficiency anemia in congenital heart disease.

\section{Acknowledgements}

The researcher would like to thank all staffs in Pediatric Cardiology at the Faculty of Medicine, University of North Sumatra for the extensive support during the study.

\section{References}

Alam, S.L.S., Purnamasari, R., Bahar, E. and Rahadian, K.Y.K., 2014. Mentzer index as a screening tool for iron deficiency anemia in 6-12year-old children. Paediatrica Indonesiana,vol. 54. No.5, pp.294-8.

Bernier, P.L., Stefanescu, A., Samoukovic, G. and Tchervenkov, C.I., 2010, January. The challenge of congenital heart disease worldwide: epidemiologic and demographic facts. In Seminars in Thoracic and Cardiovascular Surgery: Pediatric Cardiac Surgery Annual (Vol. 13, No. 1, pp. 26-34). WB Saunders.

Beverborg NG, van Veldhuisen DJ, van der Meer P, 2018. Anemia in heart failure: still relevant?. JACC: Heart Failure;6. Hh. 201-8.

Binh, T.Q., Suong, N.T.B. and Dinh, N.H., 2018. Iron deficiency anemia in children with congenital heart disease and the usefulness of erythrocyte indexes as a screening tool. Arch Gen Intern Med. Volume 2, no.3, hh.1-4.

Broberg, C.S., Bax, B.E., Okonko, D.O., Rampling, M.W., Bayne, S., Harries, C., Davidson, S.J., Uebing, A., Khan, A.A., Thein, S. and Gibbs, J.S.R., 2006. Blood viscosity and its relationship to iron deficiency, symptoms, and exercise capacity in adults with cyanotic congenital heart disease. Journal of the American College of Cardiology, vol. 48, no.2, pp.356-365.

Depkes, R.I., 2008. Riset kesehatan dasar (RISKESDAS) 2007. Badan Penelitian dan Pengembangan Kesehatan Depkes RI, Jakarta.

Depkes, R.I., 2013. Riset kesehatan dasar (RISKESDAS) 2013. Badan Penelitian dan Pengembangan Kesehatan Depkes RI, Jakarta.

Djer, M.M. and Madiyono, B., 2016. Tatalaksana penyakit jantung bawaan. Sari Pediatri, 2(3), pp.155-62

Ehsani, M.A., Shahgholi, E., Rahiminejad, M.S., Seighali, F. and Rashidi, A., 2009. A new index for discrimination between iron deficiency anemia and beta-thalassemia minor: results in 284 patients. Pakistan Journal of Biological Sciences, 12(5), pp.473-475.

Ferdian, B.A., Rosdiana, N. and Lubis, B., 2009. Impact Of Iron therapy on Mentzer Index and red cell distribution width index in primary school children with iron deficiency anemia. Paediatrica Indonesiana,vol 49, no.4, pp.195-9.

Hariyanto, D., 2016. Profil Penyakit Jantung Bawaan di Instalasi Rawat Inap Anak RSUP Dr. M. Djamil Padang Januari 2008-Februari 2011. Sari Pediatri, vol. 14. No.3, pp.152-7.

Hermawan, B.J., Hariyanto, D. and Aprilia, D., 2018. Profil Penyakit Penyakit Jantung Bawaan Di Instalasi Rawat Inap Anak RSUP Dr. M. Djamil Padang Periode Januari 2013-Desember 2015. Jurnal Kesehatan Andalas, vol.7, no.1, pp.142-148.

Maloku-Ceku, A. and Berisha, M., 2010, November. Iron deficiency anemia in children with congenital heart disease. In Pediatric Research, Vol. 68, hh.421-421

Maramis, P.P., Kaunang, E.D. and Rompis, J., 2014. Hubungan penyakit jantung bawaan dengan status gizi pada anak di RSUP Prof. Dr. RD Kandou Manado Tahun 2009-2013. e-CliniC, 2(2).

Martínez-Quintana, E. and Rodríguez-González, F., 2013. Iron deficiency anemia detection from hematology parameters in adult congenital heart disease patients. Congenital heart disease, vol. 8. No.2, pp.117-123.

Mir, A.B., Shah, J.A., Mushtaq, S. and Jan, M., 2019. Prevalence, profile of malnutrition and iron deficiency anemia in children with cyanotic congenital heart defects: a case control observational study in a tertiary care hospital in North India. International Journal of Contemporary Pediatrics, 6(3), p.1303.

Miyamoto, K., Inai, K., Takeuchi, D., Shinohara, T. and Nakanishi, T., 2015. Relationships among red cell distribution width, anemia, and interleukin-6 in adult congenital heart disease. Circulation Journal, pp.CJ-14. 
Modi, P., Suleiman, M.S., Reeves, B.C., Pawade, A., Parry, A.J., Angelini, G.D. and Caputo, M., 2004. Basal metabolic state of hearts of patients with congenital heart disease: the effects of cyanosis, age, and pathology. The Annals of thoracic surgery, vol. 78, no.5, pp.1710-1716.

Mukherjee, S., Sharma, M., Devgan, A. and Jatana, S.K., 2018. Iron deficiency anemia in children with cyanotic congenital heart disease and effect on cyanotic spells. medical journal armed forces india, vol. 74, no.3, hh.235-240.

Niazi, M., Tahir, M., e Raziq, F. and Hameed, A., 2010. Usefulness of redcell indices in differentiating microcytic hypochromic anemias. Gomal Journal of Medical Sciences, 8(2).

Nikyar, B., Sedehi, M., Mirfazeli, A., Qorbani, M. and Golalipour, M.J., 2011. Prevalence and pattern of congenital heart disease among neonates in Gorgan, Northern Iran (2007-2008). Iranian journal of pediatrics, 21(3), p.307.

Nydegger, A., Walsh, A., Penny, D.J., Henning, R. and Bines, J.E., 2009. Changes in resting energy expenditure in children with congenital heart disease. European journal of clinical nutrition,vol.63. no.3, pp.392-397.

Okoromah, C.A., Ekure, E.N., Lesi, F.E., Okunowo, W.O., Tijani, B.O. and Okeiyi, J.C., 2011. Prevalence, profile and predictors of malnutrition in children with congenital heart defects: a case-control observational study. Archives of disease in childhood, 96(4), pp.354-360.

Rose, S.S., Shah, A.A., Hoover, D.R. and Saidi, P., 2007. Cyanotic congenital heart disease (CCHD) with symptomatic erythrocytosis. Journal of general internal medicine, vol.22, no.12, pp.1775-1777.

Soni, S, Chaudhary, P, Arya, S, Thora, S, Soni, S \&Chaudhary, P, 2018. assess iron deficiency anaemia in patients with cyanotic heart disease compared to general population.International journal of pediatric research.vol.5, no.5, hh.268-272

Susan, U.A., Nnena, T.P. and Edewele, O.B., 2019. Prevalence of congenital heart diseases among primary school children in the Niger Delta Region of Nigeria, West Africa, Journal of cardiology cardiovascular medicine.p.144-149

Suyasa, A.B., Umar, N. and Oetoro, B.J., 2013. Implikasi Anestesi Pasien Cedera Kepala Traumatik dengan Penyakit Jantung Bawaan (PJB) Sianotik: Masalah Hiperviskositas Darah. Jurnal Neuroanestesi Indonesia, vol. 2, no.3, pp.166-76.

Vaidyanathan, B., Nair, S.B., Sundaram, K.R., Banu, U.K., Shivaprakasha, K., Rao, S.G. and Kumar, R.K., 2008. Malnutrition in Children with Congenital Heart Disease (CHD): Determinants and Short-term Impact of Corrective Intervention. Indian pediatrics, vol.45, no.7.

Vehapoglu, A., Ozgurhan, G., Demir, A.D., Uzuner, S., Nursoy, M.A., Turkmen, S. and Kacan, A., 2014. Hematological indices for differential diagnosis of beta thalassemia trait and iron deficiency anemia. Anemia, 2014. 